\title{
ADULT CARDIAC MYOCYTES SURVIVE AND REMAIN EXCITABLE DURING LONG-TERM CULTURE ON SYNTHETIC SUPPORTS
}

Thierry A. Folliguet, MDa

Catherine Rücker-Martin, $\mathrm{PhD}^{\mathrm{b}}$

Catherine Pavoine, $\mathrm{PhD}^{\mathrm{c}}$

Edith Deroubaix, $\mathrm{PhD}^{\mathrm{b}}$

Morgagna Henaff, $\mathrm{PhD}^{\mathrm{d}}$

Jean-Jacques Mercadier, MD, $\mathrm{PhD}^{\mathrm{d}}$

Stéphane N. Hatem, MD, PhD ${ }^{\mathrm{d}}$
Objective: Cardiomyocytes can be transplanted successfully into skeletal and cardiac muscle. Our goal was to determine the feasibility of grafting cardiomyocytes onto various synthetic supports to create an excitable and viable tissue for implantation.

Methods: Adult rat cardiomyocytes were cultured over an 8-week period onto different substitutes, including human glutaraldehyde-treated pericardium $(n=3)$, equine glutaraldehyde-treated pericardium $(n=3)$, polytetrafluoroethylene $(n=8)$, Dacron polyester $(n=16)$, and Vicryl polyglactin $(\mathrm{n}=8)$.

Results: Only the cells seeded on the Dacron survived, with the synthetic fibers colonized at 8 weeks. On the other supports, the number of myocytes progressively decreased from the first week, with their density (number of cells per square millimeter) being, after 20 days, $17 \pm 2$ on the polytetrafluoroethylene and $5 \pm 1$ on the human or equine pericardium compared with $45 \pm 3$ on the Dacron. After 8 weeks of culture on Dacron, the sarcomeric protein (sarcomeric $\alpha$-actinin) was detected in all cells. In addition, the staining was regularly arranged and well aligned in a striated pattern. Spontaneous beating activity was obtained. Moreover, electrical stimulation of the cell preparation resulted in the generation of calcium transients, the frequency of which followed the frequency of the electrical stimulation.

Conclusions: These results suggest that adult cardiac myocytes remain viable and excitable during long-term culture on a 3-dimensional Dacron support, which might constitute a new synthetic cardiac tissue. (J Thorac Cardiovasc Surg 2001;121:510-9)
C ardiac substitutes for both intracardiac and extracardiac repairs include autologous pericardium, bovinetreated pericardium, polytetrafluoroethylene* (PTFE), Dacron polyester, and Vicryl polyglactin. The problems associated with the use of biologic and synthetic materials are widely known and include calcification, ${ }^{1}$ loss of pliability, ${ }^{2}$ bacterial seeding, and fibrotic peel formation. ${ }^{3}$

From the Department of Cardiac Surgery, ${ }^{a}$ Institut Mutualiste Montsouris, and Centre d'Expérimentation et de Recherche Appliquée, Paris; the CNRS ESA 8078, b Hôpital MarieLannelongue, Le Plessis-Robinson; the INSERM U 99, ${ }^{c}$ Hôpital H. Mondor, Créteil; and the INSERM U 460, ${ }^{\mathrm{d}}$ Hôpital X. Bichat, Paris, France.

Supported in part by grants from the INSERM and Foundation de l'Avenir.

*Gore-Tex; registered trade name of W. L Gore \& Associates, Inc, Flagstaff, Ariz.

Copyright $\odot 2001$ by The American Association for Thoracic Surgery

$0022-5223 / 2001 \$ 35.00+0 \quad \mathbf{1 2 / 1 / 1 1 2 5 2 8}$

doi: $10.1067 / \mathrm{mtc} .2001 .112528$
More recently, developments in the storage of homografts, such as cryopreservation, led to the hope for longterm durability, particularly in children. However, some series show a disappointing long-term outcome of homografts implanted in the pulmonary circulation. ${ }^{4}$ At this point, no substitutes used for cardiac or vascular repair can grow or remodel throughout the life span.

In an attempt to overcome some of these problems, others have used skeletal muscles as a viable substitute to repair the human heart. ${ }^{5}$ However, cardiomyoplasty has substantial limitations linked to the conditioning of the muscle fibers.

Recently, advances in cellular biology have opened the possibility of additional approaches to repair myocytes and to replace the myocardium. Experimentally, cellular transplantation to the heart has been performed with transformed cell lines, ${ }^{6,7}$ satellite cells, ${ }^{8}$ smooth muscle cells, ${ }^{9}$ and bone marrow stromal cells ${ }^{10}$ as the donor cells. Recent studies have shown that fetal cardiomyocytes could be genetically marked or modi- 
fied before being grafted to the heart, ${ }^{11}$ with the formation of nascent intercalated disks connecting the grafted fetal cardiomyocytes to the host myocardial cells. ${ }^{12}$ Recently, autologous endothelial cell seeding on PTFE vascular prostheses was used for coronary artery bypass grafts in human subjects with good results. ${ }^{13}$

Others have demonstrated the feasibility of transplanting fetal rat cardiomyocytes into the hearts of adult rats and also shown that these cells can colonize the periinfarct area ${ }^{14}$ and improve ventricular function, ${ }^{15,16}$ with the cells contracting after being stimulated. ${ }^{16}$ Finally, others have created, with fetal cardiomyocytes, a functional cardiac tissue on a 3 -dimensional mesh. ${ }^{17}$

Several studies of the literature have shown that it is possible to maintain adult cardiac myocytes in longterm primary cultures, ${ }^{18-21}$ including human atrial myocytes $^{22,23}$ on 2-dimensional supports coated mainly with laminin and with a culture medium supplemented with fetal serum, which provides growth factors. In these cultured conditions, myocytes undergo a marked growth and dedifferentiation process, pointing to the remarkable plasticity of these terminally differentiated myocytes to adapt to new environmental conditions. ${ }^{20,21,24-26}$ However, it remains to be determined whether isolated adult cardiomyocytes can be grafted onto various meshes and used as a cardiac substitute.

In the present study, using rat ventricular myocytes in primary cultures, the following questions were addressed. Which synthetic cardiac substitute allows cardiac myocytes to survive? Does this tissue culture system show functional properties of a myocardium?

\section{Materials and methods}

Tissue supports. Four different substitutes were tested: human glutaraldehyde-treated pericardium $(n=3)$, equine glutaraldehyde-treated pericardium ( $\mathrm{n}=3$, Baxter-Edwards), PTFE ( $\mathrm{n}=8$, patch1-mm thickness), single velour woven polyester patch $(\mathrm{n}=16$, Dacron patch, Meadox Cardiovascular Fabrics, Oakland, NJ), and polyglactin $910(\mathrm{n}=8$, Vicryl patch style 9, Ethicon, Inc, Somerville, NJ). For each substitute, both sides were tested. For the polyester, we tested a knitted fabric, which is composed of a smooth nonvelour surface on one side, with microloops of textured yarn on the other.

Culture of cardiac myocytes and Ad.RSV.LacZ infection. All animals received humane care in compliance with the "Principles of Laboratory Animal Care" formulated by the National Society for Medical Research and the "Guide for the Care and Use of Laboratory Animals" prepared by the Institute of Laboratory Animal Resources, National Research Council, and published by the National Academy Press, revised 1996. Adult male Wistar rat ventricular myocytes were isolated, as previously described. ${ }^{27,28}$ In brief, rats were deeply anesthetized with sodium pentobarbital $(50 \mathrm{mg} / \mathrm{kg}$ administered intraperitoneally), and hearts were quickly excised and perfused in a ret- rograde manner ( $8 \mathrm{~mL} / \mathrm{min}$ ) by use of a Langendorff apparatus with Krebs buffer containing $4.75 \mathrm{mmol} / \mathrm{L} \mathrm{KCl}, 35 \mathrm{mmol} / \mathrm{L}$ $\mathrm{NaCl}, 1.2 \mathrm{mmol} / \mathrm{L} \mathrm{KH}_{2} \mathrm{PO}_{4}, 16 \mathrm{mmol} / \mathrm{L} \mathrm{Na}_{2} \mathrm{HPO}_{4}, 25 \mathrm{mmol} / \mathrm{L}$ $\mathrm{NaHCO}_{3}, 10 \mathrm{mmol} / \mathrm{L}$-2-hydroxyethylpiperazine- $\mathrm{N}$-2-ethanesulfonic acid, $10 \mathrm{mmol} / \mathrm{L}$ glucose, and $134 \mathrm{mmol} / \mathrm{L}$ sucrose $(\mathrm{pH}$ 7.4) at $37^{\circ} \mathrm{C}$ and then with the same buffer containing collagenase $(0.62 \mathrm{IU} / \mathrm{mL}$, Boehringer Mannheim, GmbH, Mannheim, Germany) and hyaluronidase (147 IU/mL, Sigma-Aldrich Corporation, St Louis, Mo). After several low-speed centrifugation $(10 \mathrm{~g})$ and sedimentation steps, myocytes were resuspended $(90,000$ viable myocytes $/ \mathrm{mL})$ in Dulbecco's modified Eagle's medium supplemented with $10 \%$ fetal calf serum (which provides growth factors; BioWhittaker, Inc, a Cambrex Company, Walkersville, Md), nonessential amino acids, 1 $\mathrm{nmol} / \mathrm{L}$ insulin, and antibiotics $(100 \mathrm{IU} / \mathrm{mL}$ penicillin and 0.1 $\mu \mathrm{g} / \mathrm{mL}$ streptomycin) and plated (day 0) on the different supports precoated with $10 \mu \mathrm{g} / \mathrm{mL}$ laminin (Gibco BRL, Life Technologies, Inc, Rockville, Md) at a final cellular density of around 200,000 cells $/ \mathrm{mL}$. This technique has been shown to yield less than $3 \%$ of nonmuscle cells in the cultures based on staining of the sarcomeric apparatus with anti- $\alpha$-actinin immunoglobulin. ${ }^{27,29}$ In addition, to inhibit the proliferation of nonmuscle cells, the antimitotic agent cytosine arabinose (10 $\mu \mathrm{mol} / \mathrm{L}$, Sigma-Aldrich) was added throughout the culture period. ${ }^{30,31}$ Culture medium was renewed at day 1 and every other day thereafter. To determine plating efficiency and myocyte viability during culture, cells were infected with an adenovirusmediated LacZ (a recombinant replication-defective adenovirus derived from human adenovirus type 5 [Ad.RSV.LacZ]) at 40 pfu per cell for 1 hour. ${ }^{32}$ After virus exposure, the culture medium was promptly removed, and cells were washed twice with virus-free culture medium and incubated at $37^{\circ} \mathrm{C}$ until the determination of the LacZ gene expression. Therefore, cultured cells were washed in phosphate-buffered saline solution (PBS) and fixed with glutaraldehyde $(0.2 \%)$-formaldehyde $(1 \%)$, and $\beta$ galactosidase activity was detected by incubation in PBS containing $4 \mathrm{mmol} / \mathrm{L} \mathrm{K}_{3} \mathrm{Fe}(\mathrm{CN})_{6}, 4 \mathrm{mmol} / \mathrm{L} \mathrm{K}_{4} \mathrm{Fe}(\mathrm{CN})_{6}, 2 \mathrm{mmol} / \mathrm{L}$ $\mathrm{MgCl}_{2}$, and $400 \mu \mathrm{g} / \mathrm{mL} \mathrm{X}$-gal. The myocyte density was determined by examining 10 randomly selected high-power microscope fields $(200 \times)$.

Immunohistochemistry. Myocytes were subjected to indirect immunofluorescence labeling of sarcomeric $\alpha$-actinin. In brief, myocytes were fixed with $4 \%$ paraformaldehyde, washed in PBS, and then incubated in blocking buffer (2\% bovine serum albumin in PBS) to block nonspecific sites. To detect the distribution of the sarcomeric $\alpha$-actinin, cells were exposed to monoclonal antibodies directed against sarcomeric $\alpha$-actinin (1:400, Sigma). These antibodies were derived from the EA-53 hybridoma produced by the fusion of mouse myeloma cells and splenocytes from BALB/c mice immunized with purified rabbit skeletal $\alpha$-actinin. It is specific for anti- $\alpha$-skeletal muscle actinin and $\alpha$-cardiac muscle actinin. It stains $\mathrm{Z}$ lines and dots in stress fibers of myotubules in skeletal and cardiac muscle but not in nonsarcomeric muscle elements (ie, connective tissue, epithelium, nerves, and smooth muscle). This step was followed by horse biotinylated anti-mouse immunoglobulin $\mathrm{G}$ (IgG) antibodies (1:30, Vector Laboratories, Inc, Burlingame, Calif) and streptavidin 
Texas red (1:30, Amersham Corp, Arlington Heights, Ill). After a final wash, coverslips were mounted in a mounting medium (Fluoprep, Pasteur Merieux Connaught, Lyon Cedex, France). In control experiments the above protocol was used, except that the incubation step with specific antibodies was omitted. Slides were examined with a Leica DMLB fluorescence microscope (Leica Microsystems Inc, Deerfield, Ill) equipped with N2.1 filter for Texas red and a Sony 3 CCD DXC 930P color camera. The resulting images were printed with a Sony UP5600 video color printer (Sony Electronics, Inc, Park Ridge, NJ).

Confocal observations were carried out with an MRC-1024 (Bio-Rad Laboratories, Hercules, Calif) confocal scanning laser with a microscope (Nikon Optiphot Fluorescence, Nikon Inc, Instrument Group, Huntington Station, NY) by using Lasersharp version 2.0 software (Bio-Rad). Discrete photon counting gave a sharp visualization of weak label, even with the highest $(\mathrm{x}, \mathrm{y})$ calibration $\left(6.2\right.$ pixels $\left./ \mathrm{mm}^{1}\right)$. A multiple-line Krypton-Argon ion laser beam (Bio-Rad) was operated at full power $(15 \mathrm{~mW})$ and attenuated with a neutral density filter to obtain $30 \%$ of maximal laser intensity. The microscope was operated in the fluorescent mode. The detection pinhole was set to minimum to give the thinnest possible optical section. An excitation filter at $568 \mathrm{nmol} / \mathrm{L}$ and an emission filter at $605 \mathrm{nmol} / \mathrm{L}$ were used for Texas Red fluorescence, with a gain of $1200 \mathrm{~V}$ and an iris of $2.1 \mathrm{~mm}$.

$\mathbf{C a}^{2+}$ transient measurements. Cell myocytes were bathed in $2 \mathrm{~mL}$ of saline buffer containing $10 \mathrm{mmol} / \mathrm{L}$ glucose, 130 $\mathrm{mmol} / \mathrm{L} \mathrm{NaCl}, 5 \mathrm{mmol} / \mathrm{L} \mathrm{KCl}, 10 \mathrm{mmol} / \mathrm{L}$-2-hydroxyethylpiperazine- $\mathrm{N}$-2-ethanesulfonic acid buffered at $\mathrm{pH} 7.4$ with Tris base, $1 \mathrm{mmol} / \mathrm{L} \mathrm{MgCl}_{2}$, and $2 \mathrm{mmol} / \mathrm{L} \mathrm{CaCl}_{2}$ and were incubated for 40 minutes at $25^{\circ} \mathrm{C}$ with $1.5 \mu \mathrm{mol} / \mathrm{L}$ Fura 2-AM ( $3 \mu \mathrm{L}$ of $1 \mathrm{mmol} / \mathrm{L}$ Fura 2 -AM in dimethylsulfoxide; Molecular Probes, Inc, Eugene, Ore) in the presence of 1 $\mathrm{mg} / \mathrm{mL}$ bovine serum albumin (Sigma) to improve Fura 2AM dispersion and facilitate cell loading. Grafts were then washed with saline buffer $(2 \times 2 \mathrm{~mL})$ and allowed to incubate in the same buffer for 30 minutes at $25^{\circ} \mathrm{C}$ to facilitate hydrolysis of intracellular Fura 2-AM. Ca_ ${ }^{+}$imaging, developed by A. Trauman in collaboration with the IMSTAR Co (Paris, France), was essentially as described by Sauvadet and colleagues. ${ }^{33}$ Field electrical stimulation (square waves, 2-ms duration, and amplitude $20 \%$ above threshold) was supplied through a pair of platinum electrodes connected to the output of a HAMEG stimulator (Paris, France). During the experiments, cells were superfused with saline buffer.

Statistical analysis. All data are presented as means \pm SEM. Kruskal-Wallis analysis of variance on ranks followed by the Dunnett test were used for the statistical comparison of multiple groups.

\section{Results}

Cellular characterization. First, we checked that after 3 weeks of culture, the vast majority of cells were cardiac myocytes and that they could survive and grow by performing double immunostaining with antibodies directed against sarcomeric $\alpha$-actinin and fibronectin to discriminate between myocytes and fibroblasts, respectively. This was indicated by the observation that at this stage of culture, more than $85 \%$ of the cells were stained with antibodies directed against sarcomeric $\alpha$-actinin, whereas only a few cells were positive with antifibronectin immunoglobulins, which specifically stained fibroblasts (Fig 1, $A$ and $B$ ). Of note, the nonmuscle cells present in the culture were positive with antifibronectin immunoglobulins but unreactive to antisarcomeric $\alpha$ actinin immunoglobulins, indicating that these latter only stained cardiac myocytes (Fig $1, C$ and $D$ ). These experiments were performed on 2-dimensional culture dishes to optimize cell identification and counting.

Dacron support allowed a prolonged survival of myocytes in culture. In the first set of experiments, we tested the capacity of cardiac myocytes to survive on various supports, including human or equine pericardium, or synthetic tissues, such as PTFE, Vicryl, and Dacron supports. To identify and quantify myocytes in culture, cells were transfected just after the isolation with an adenovirus encoding for the $\beta$ galactosidase. The adenovirus was used at a multiplicity of infection known to not alter the capacity of myocytes to survive and grow in culture. ${ }^{7}$ After 1 week in culture, ventricular myocytes attached more efficiently to Dacron weave $(81 \pm 2$ myocytes with positively X-gal-stained nuclei per square millimeter) than to other supports (smooth Dacron, $56 \pm 8$ myocytes $/ \mathrm{mm}^{2}$; PTFE, $69 \pm 4$ myocytes $/ \mathrm{mm}^{2}$; and pericardium, $65 \pm 5$ myocytes $/ \mathrm{mm}^{2}$ ). This increased adhesion on Dacron supports was consistently observed after 3 weeks in culture in contrast to results found with other supports (Fig 2).

On PTFE support after 3 weeks of culture, we observed only $17 \pm 2$ myocytes $/ \mathrm{mm}^{2}$, which represents a loss of $75 \%$ of myocytes detected at day 7 . On pericardium, cardiac myocytes with positively X-gal-stained nuclei were observed after 3 weeks, but these cells exhibited no growth process, maintained a round-shaped morphology, and were all labeled with trypan blue, indicating alteration of their membrane integrity. In contrast, on the Dacron patch, predominantly on the nonsmooth side, 45 \pm 3 viable myocytes $/ \mathrm{mm}^{2}$ were still present. This is illustrated in Fig 3, which shows that only a few dispersed myocytes remained after 3 weeks of culture on the pericardium (Fig 3, $A$ ) and PTFE support (Fig 3, $B$ and $E$ ), whereas Dacron patches at the same time were entirely colonized by myocytes ( $\mathrm{n}=5$; Fig $3, C$ and $D)$. At higher magnification, it can be seen that myocytes have grown along the Dacron structure, resulting in an apparent wrapping of the tissue fibers (Fig 3,F), which is contrary to PTFE support where myocytes spread out, creating only a few expansions (Fig 3,E). In contrast, cells adhered on 

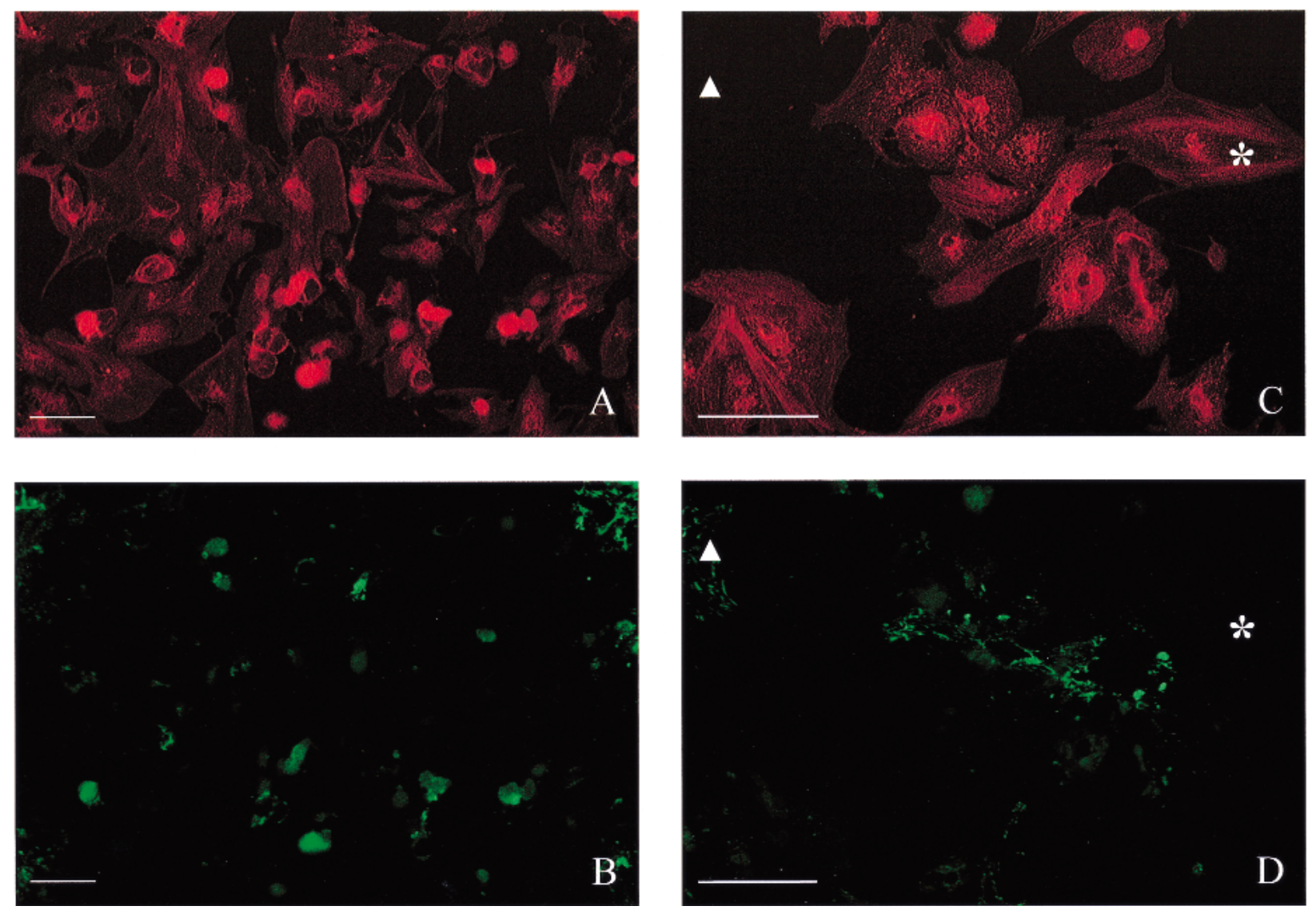

Fig 1. Myocytes cultured for 15 days were incubated with antisarcomeric $\alpha$-actinin $(\mathbf{A}$ and $\mathbf{C})$ and antifibronectin (B and D) immunoglobulins. Only myocytes were stained with antisarcomeric $\alpha$-actinin $(*)$. In contrast, the nonmuscle cells were labeled with antifibronectin and not with antisarcomeric $\alpha$-actinin (triangles; bar $=50 \mu \mathrm{m}$ ).

the Vicryl patch, but they lost their architectural organization because the Vicryl support dissolved around the fourth week.

\section{Evidence for structural differentiation of cultured} myocytes on Dacron tissue. Structural characterization of cultured myocytes was performed by means of the immunocytochemistry technique with a monoclonal antibody directed against the sarcomeric $\alpha$-actinin. After 3 weeks of culture, both on PTFE and Dacron tissues, the sarcomeric protein was detected; however, in the former the staining was organized in an irregular packed pattern, with only a few areas of striated organization, suggesting a certain degree of cellular atrophy (Fig 4, $A$ and $B$ ).

On the Dacron support, the staining was regularly arranged and well aligned in a striated pattern (Fig 4, $B$ ). With confocal microscopy used to examine the cellular preparation in different planes with a micrometric resolution, it was possible to visualize a continuous section of a given tissue fiber stained with sarcomeric $\alpha$-actinin antibody. This is illustrated in Fig 5, which shows, after 8 weeks of culture, that fibers of the Dacron tissue were regularly striated through the body (Fig 5, A), with a more intense staining at the periphery (Fig 5, B). In addition, it can be seen that myocytes reestablished contact between themselves on contiguous fibers. Taken together, these results indicate that Dacron fibers were entirely wrapped with myocytes that had regained a sarcomeric apparatus, resulting in a multilayer of structurally differentiated myocytes.

Myocytes cultured on Dacron tissue remained excitable. The aim of the next set of experiments was to determine the functionality of myocytes cultured on the Dacron support. Visualization of cellular preparations with phase contrast microscopy revealed that when myocytes reached confluence around 4 to 6 weeks of culture, they beat spontaneously when exposed to room temperature. ${ }^{22}$ The beating appeared to arise initially from a group of myocytes and then spread out, resulting in an apparent synchronous activ- 


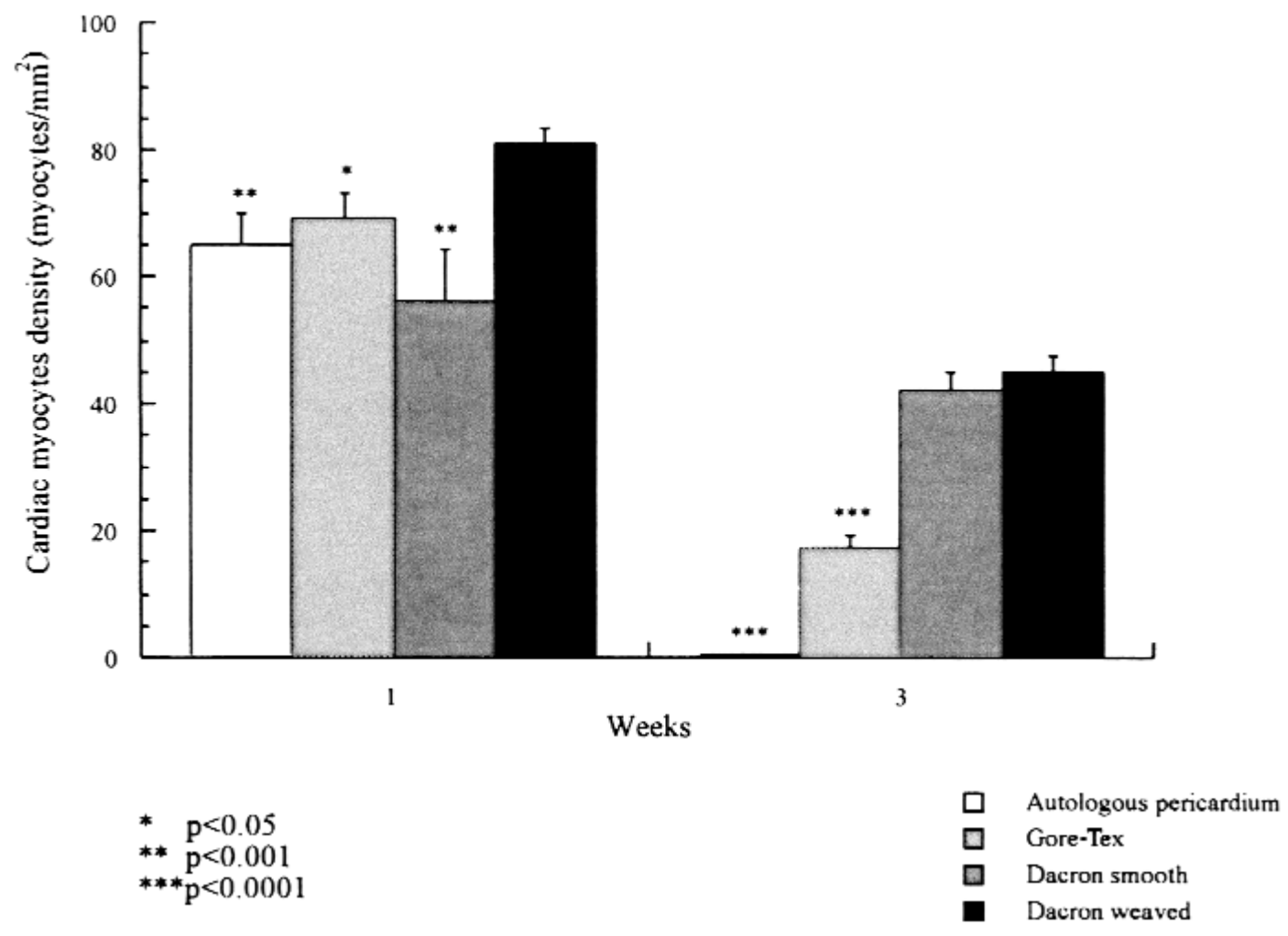

Fig 2. Density of cardiac myocytes grown on various supports after 1 and 3 weeks in culture.

ity, which indicated that cells developed a contractile activity. However, attempts to record cellular action potential by using the $\mathrm{KCl}$ filled-microelectrode technique were unsuccessful, mainly because of the thickness of the cellular monolayer and the complex 3dimensional architecture of the support. In cardiac myocytes phasic changes in $\left[\mathrm{Ca}^{2+}\right]_{\mathrm{I}}$ and $\mathrm{Ca}_{\mathrm{i}}$ transients is caused by the $\mathrm{Ca}^{2+}$ ions flowing through the L-type $\mathrm{Ca}^{2+}$ channels, which open during the action potential and which activate the released channels of the sarcoplasmic reticulum $\left(\mathrm{Ca}^{2+}\right.$-induced and $\mathrm{Ca}^{2+}$ released). ${ }^{34}$ To overcome the technical difficulty of recording action potential and as a reliable test for the functionality of cultured myocytes, changes in intracellular free $\mathrm{Ca}^{2+}$ concentration were measured in cells loaded with the permeant form of the $\mathrm{Ca}^{2+}$ dye, fura 2 . Cellular preparations from an 8-week culture were electrically stimulated at different frequencies. Fig 6 shows the pattern of $\mathrm{Ca}_{\mathrm{i}}$ transients triggered by electrical stimulation. The frequency of calcium transients paralleled the frequency of electrical stimulation. In addition, cells of the field of the microscope presented synchronous calcium responses that suggested functional connections between cells.

\section{Discussion}

The main finding of this study is that adult rat cardiomyocytes can be grafted onto a 3-dimensional substitute and cultured up to 8 weeks.

We found that myocytes, when cultured on synthetic supports, maintain several of their structural and functional properties, suggesting that such a culture system may provide a viable and functional cardiac support. These synthetic tissues are either woven or knitted, and some are velour, which exhibits superior tissue ingrowth. On the velour variety of Dacron, cells synthesized new myofibrils regularly organized in a sarcomeric pattern, suggesting the reconstitution of a contractile apparatus. Adult cardiac myocytes cultured on 2-dimensional plastic dishes in the presence of serum undergo an extensive growth and dedifferentiation process, followed by a redifferentiation phase, during which they regain a cardiac phenotype..$^{20,21,35}$ It is likely that a similar cellular remodeling process occurred on the Dacron support, and this explains how 8 weeks after their isolation, well-sarcomerized myocytes can colonize and wrap the synthetic fibers. The fact that Dacron is a 3-dimensional structure probably helps in the colonization and attachment of the various car- 

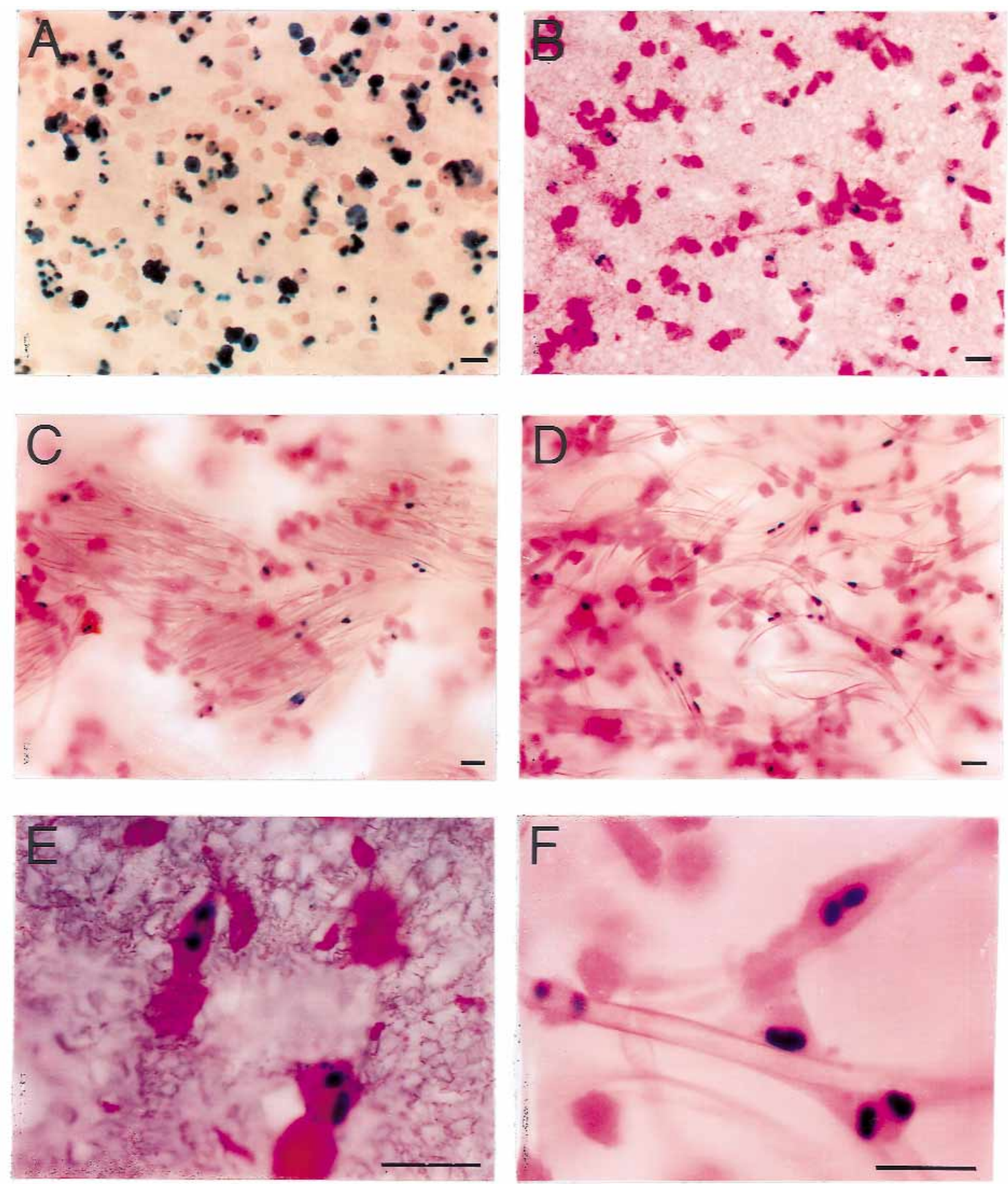

Fig 3. Photomicrograph of cardiac myocytes grown on the various tested supports. A, Pericardium; $\mathbf{B}$ and $\mathbf{E}$, PTFE; C, smooth Dacron; D and E, woven Dacron after 3 weeks in culture (bar $=50 \mu \mathrm{m})$. Transfected myocytes with Ad.RSV.LacZ were revealed as having $\beta$-galactosidase activity being responsible for the blue staining of their nuclei.

diomyocytes. We tested Dacron because it is a commonly used substitute in vascular and cardiac replacement; however, we have doubt concerning its clinical use as a substitute for cardiac replacement because its compliance is extremely low. Therefore, a new scaffold 3-dimensional structure potentially colonized by cardiomyocytes has to be developed as a patch substitute for in vivo reconstruction.

To our knowledge, little is known of the ability of adult cardiomyocytes to colonize synthetic tissue, 

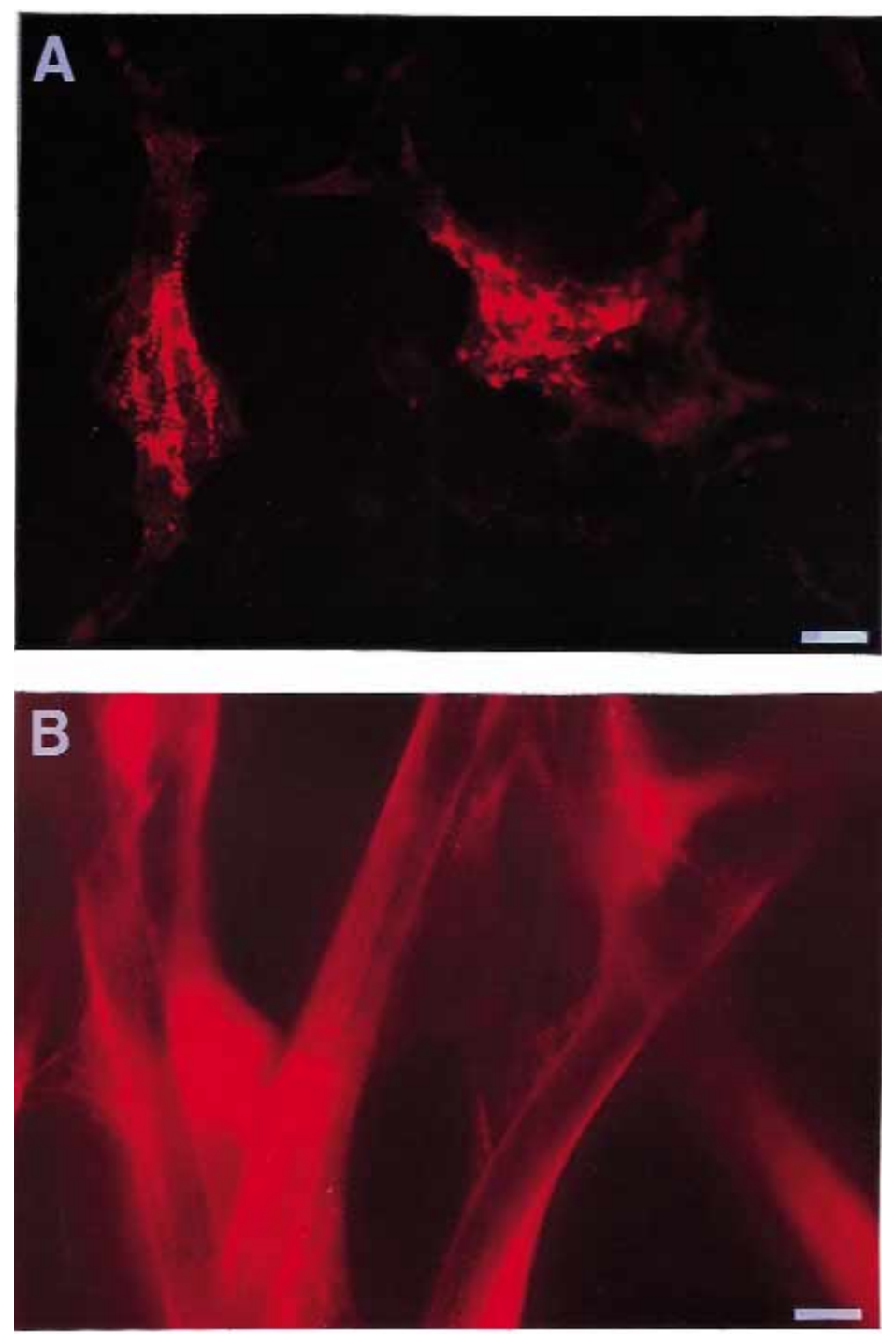

Fig 4. Sarcomeric $\alpha$-actinin labeling performed on myocytes grown on PTFE (A) and Dacron (B) supports after 3 weeks of culture $($ bar $=50 \mu \mathrm{m})$.

including the surface chemistry and surface microstructure, which influence cells to attach, grow, and function normally. ${ }^{36}$ The ideal tissue should allow a rapid grafting of the cells, with a slow resorption of the substitute to allow firm connections between the myocytes and the receiving host. Our results show that human and equine pericardium do not allow long-term survival of myocytes. This is probably because of the cellular toxicity of glutaraldehyde, which persisted despite the fact that the support had been amply rinsed and washed. Therefore, another cross-linking agent should be used for cells to attach and grow on pericardium. The advantage of pericardium is its easy availability; however, its disadvantage is its 2-dimensional surface. Limited adhesion of myocytes was also obtained by using PTFE sheets as culture supports. Concerning Vicryl substitute, it dissolves in 4 to 6 weeks and allows formation of a neostructure with angiogenesis. ${ }^{37}$ However, in our study, although Vicryl allowed survival of the cardiomyocytes for 3 weeks, at the time it started to dissolve, myocytes probably died as the result of a marked acidification of the culture medium.

The observation that tissues respond to electrical field stimulation by $\mathrm{Ca}_{\mathrm{i}}$ transients, which followed the rate of the electrical stimulation, indicate that myocytes in primary culture on Dacron tissue kept their main excitable characteristics and that their electrical activity is coupled to the intracellular release of $\mathrm{Ca}^{2+}$ process. From these observations, it can be deduced 

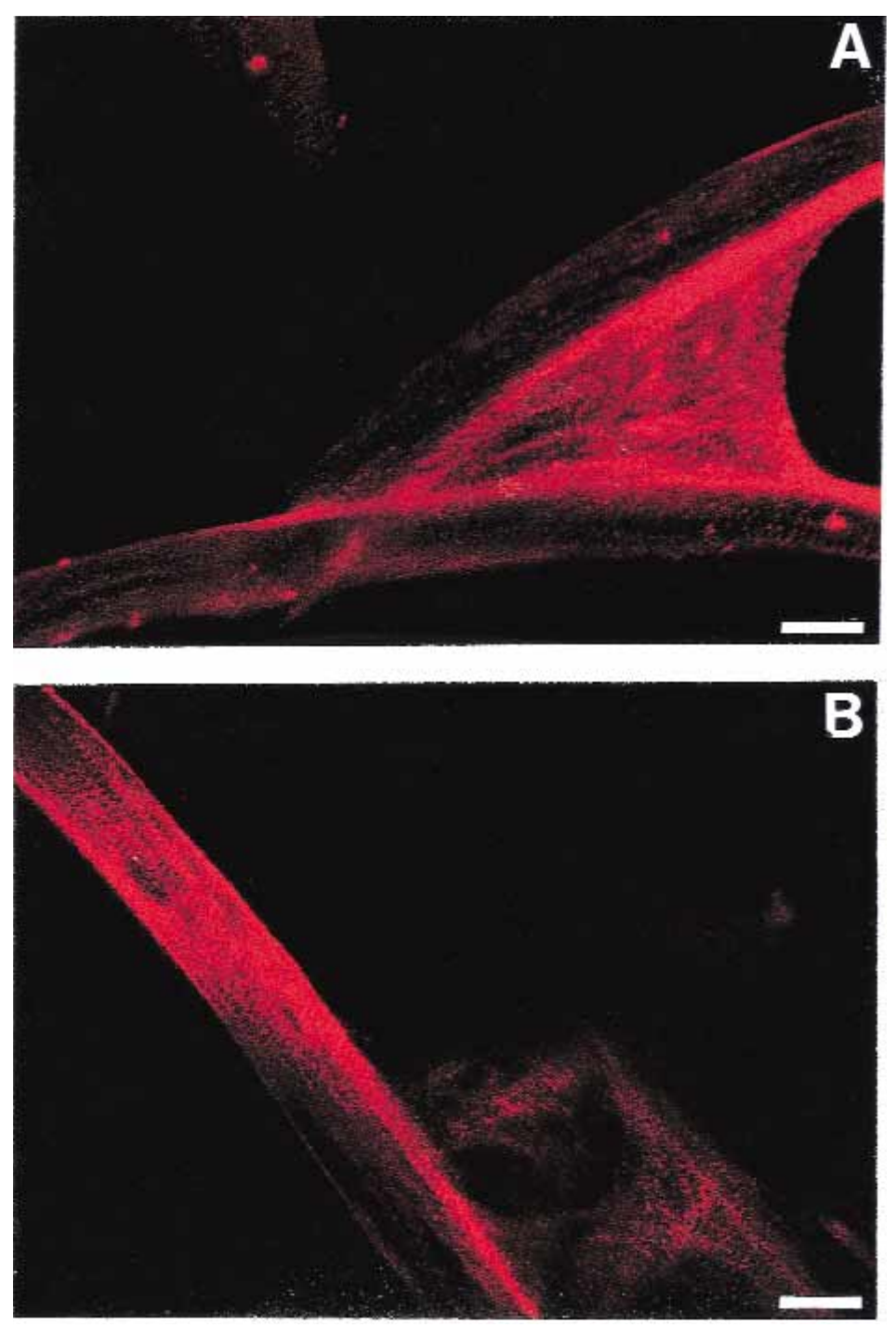

Fig 5. Confocal microscopy visualization of $\alpha$-actinin sarcomeric staining organized in a striated pattern in myocytes grown for 8 weeks. A, Myocytes intercalated between two Dacron fibers. B, Myocyte wrapped around Dacron fibers $($ bar $=50 \mu \mathrm{m})$.

that in 8-week cultured myocytes (1) mechanisms responsible for cellular excitability are functional; (2) there is a voltage-dependent intracellular $\mathrm{Ca}^{2+}$ entry process, probably the L-type $\mathrm{Ca}^{2+}$ channels, ${ }^{22}$ which trigger the release of $\mathrm{Ca}^{2+}$ from the sarcoplasmic reticulum; and (3) there are repolarizing currents that bring the system back to a rest state. These findings are consistent with studies in the literature showing that in long-term primary cultures cardiac myocytes maintain their physiologic properties despite a certain degree of dedifferentiation. ${ }^{22,38}$ Thus, it seems clear that the monolayer or multilayer of myocytes that have colonized and covered all the tissue fibers after a few weeks in vitro is an excitable tissue characterized by a func- tional excitation-contraction coupling process. This raises questions as to whether it could constitute a new biologic material.

Tissue engineering is a new and very active discipline that offers the potential to create replacement structures from autologous cells and biodegradable polymers. ${ }^{39}$ Engineering of cardiac valve leaflets ${ }^{39,40}$ and large conduit arteries ${ }^{41}$ has been performed, owing to a cellular approach. This tissue is being developed with the introduction of polyglycolic acid to form a biodegradable polymer scaffold. ${ }^{36}$ Concerning cardiac tissue, studies have been performed on various supports with only fetal rat cardiomyocytes. ${ }^{17}$ However, in clinical practice it would be difficult to create a cardiac tissue with fetal 
$0.25 \mathrm{~Hz}$

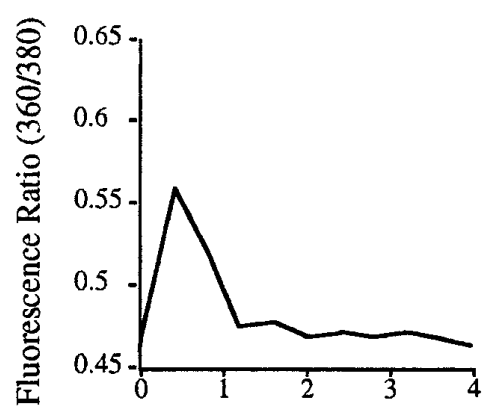

$0.5 \mathrm{~Hz}$

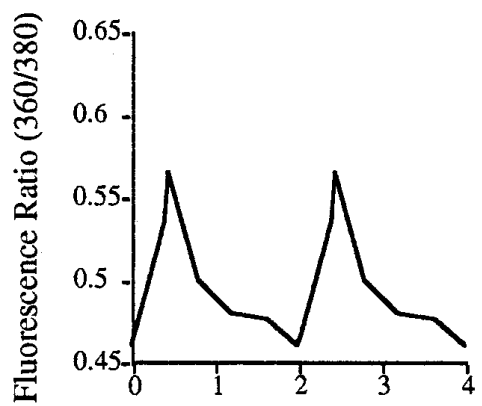

\section{$0.75 \mathrm{~Hz}$}

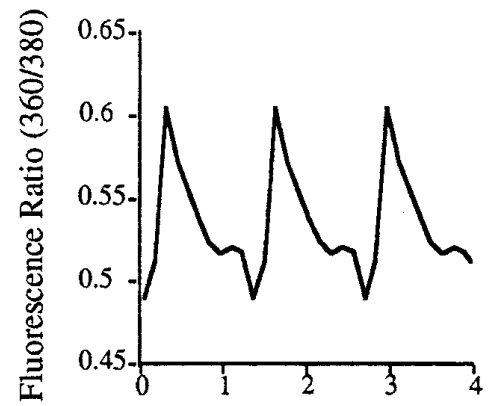

$1 \mathrm{~Hz}$

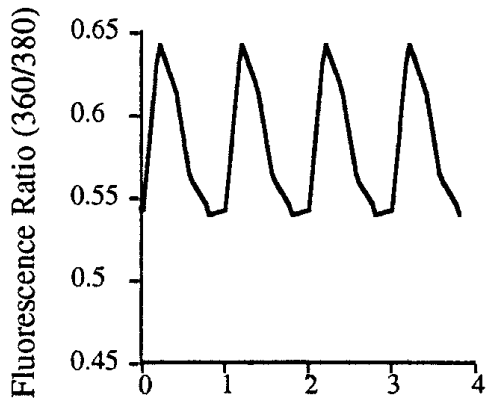

Time (s)

Fig 6. Electrical field stimulation responses of cells cultured for 8 weeks on Dacron fibers. Cardiomyocytes loaded with Fura- 2 were electrically stimulated at $0.25,0.5,0.75$, and $1 \mathrm{~Hz}$. Each trace is an average of 10 steady-state transients in a single cell. Data are representative of at least 5 cells obtained from 2 different grafts.

cells, whereas by using adult myocytes, it would be possible to construct a viable tissue with autologous cells, which could be provided from transvenous endocardial biopsy specimens. In addition, this would circumvent the problem of rejection, which requires the maintenance of cyclosporine (INN: ciclosporin) and makes it unsuitable for long-term study in a large-animal model and in a human model. ${ }^{42}$ Because of these multiple problems related to the use of fetal cells and our experience with adult human cells, ${ }^{22,23}$ we chose to work with adult cells in an animal model. The limitations involved with adult cardiac myocytes are the absence of mitosis and possibility of these cells to proliferate ${ }^{43}$ and therefore the procurement of a large quantity of cells needed to seed the patches. However, it remains important to test, in a future study, the feasibility of grafting autologous adult cardiac cells in a large-animal model.

Received for publication May 31, 2000; revisions requested Sept 8, 2000; revisions received Sept 27, 2000; accepted for publication Oct 27, 2000.

Address for reprints: T. A. Folliguet MD, FACS, Department of Cardiac Surgery, L'Institut Mutualiste
Montsouris, 42 Boulevard Jourdan, 75674 Paris cedex 14, France (E-mail: thierry.folliguet@imm.fr).

\section{REFERENCES}

1. Gabbay S, Bortolotti U, Factor S, Shore DF, Frater RW. Calcification of implanted xenograft pericardium. Influence of site and function. J Thorac Cardiovasc Surg 1984;87:782-7.

2. Nunn DB, Pourdeyhimi B. Intrinsic Dacron graft failure 19 years post-implantation. Cardiovasc Surg 1997;5:333-8.

3. Agarwal K, Edwards W, Feldt R, Danielson G, Puga F, McGoon D. Pathogenesis of nonobstructive fibrous peels in right-sided porcine-valved extracardiac conduits. J Thorac Cardiovasc Surg 1982;83:584-9.

4. Cleveland D, Williams W, Razzouk A, Trusler GA, Rebeyka IM, Duffy L, et al. Failure of cryopreserved homograft valved conduits in the pulmonary circulation. Circulation 1992;86(Suppl 5):II-150-3.

5. Chachques JC, Marino JP, Lajos P, Zegdi R, D'Attellis N, Fornes $\mathrm{P}$, et al. Dynamic cardiomyoplasty: clinical follow-up at 12 years. Eur J Cardiothorac Surg 1997;12:560-8.

6. Koh G, Soonpaa M, Klug M, Pride HP, Cooper BJ, Zipes DP, et al. Stable fetal cardiomyocyte grafts in the hearts of dystrophic mice and dogs. J Clin Invest 1995;96:2034-42.

7. Lanson NA Jr, Glembotski CC, Steinhelper ME, Field LJ, Claycomb WC. Gene expression and atrial natriuretic factor processing and secretion in cultured AT-1 cardiac myocytes. Circulation 1992;85:1835-41. 
8. Marelli D, Desrosiers C, el-Alfy M, Kao RL, Chiu RC. Cell transplantation for myocardial repair: an experimental approach. Cell Transplant 1992;1:383-90.

9. Li R, Jia Z, Weisel R, Merante F, Mickle D. Smooth muscle cell transplantation into myocardial scar tissue improves heart function. J Mol Cell Cardiol 1999;31:513-22.

10. Makino S, Fukuda K, Miyoshi S, Konishi F, Kodama H, Pan J, et al. Cardiomyocytes can be generated from marrow stromal cells in vitro. J Clin Invest 1999;103:697-705.

11. Gojo S, Kitamura S, Hatano O, Takakusu A, Hashimoto K, Kanegae Y, et al. Transplantation of genetically marked cardiac muscle cells. J Thorac Cardiovasc Surg 1997;113:10-8.

12. Soonpaa M, Koh G, Klug M, Field L. Formation of nascent intercalated disks between grafted fetal cardiomyocytes and host myocardium [see comments]. Science 1994;264:98-101.

13. Laube H, Duwe J, Rutsch W, Konertz W. Clinical experience with autologous endothelial cell-seeded polytetrafluoroethylene coronary artery bypass grafts. J Thorac Cardiovasc Surg 2000;120:134-41.

14. Connold AL, Frischknecht R, Dimitrakos M, Vrbova G. The survival of embryonic cardiomyocytes transplanted into damaged host rat myocardium. J Muscle Res Cell Motil 1997;18:63-70.

15. Scorsin M, Hagege A, Marotte F, Mirochnik N, Copin H, Barnoux $\mathrm{M}$, et al. Does transplantation of cardiomyocytes improve function of infarcted myocardium? Circulation 1997;96(Suppl 9):II-188-93.

16. Li R, Mickle D, Weisel R, Mohabeer MK, Zhang J, Rao V, et al. Natural history of fetal rat cardiomyocytes transplanted into adult rat myocardial scar tissue. Circulation 1997;96(Suppl 9):II-179-87.

17. Li RU, Jia ZQ, Weisel RD, Mickle DAG, Choi A, Yau TM. Survival and function of bioengineered cardiac grafts. Circulation 1999;100 (Suppl):II-63-9.

18. Powell T, Twist V. A rapid technique for the isolation and purification of adult cardiac muscle cells having respiratory control and a tolerance to calcium. Biochem Biophys Res Commun 1976;72:327-33.

19. Jacobson S, Piper H. Cell cultures of adult cardiomyocytes as models of the myocardium. J Mol Cell Cardiol 1986;18:661-78.

20. Eppenberger ME, Hauser I, Baechi T, Schaub MC, Brunner UT, Dechesne CA, et al. Immunocytochemical analysis of the regeneration of myofibrils in long-term cultures of adult cardiomyocytes of the rat. Dev Biol 1988;130:1-15.

21. Eppenberger-Eberhardt M, Flamme I, Kurer V, Eppenberger HM. Reexpression of alpha-smooth muscle actin isoform in cultured adult rat cardiomyocytes. Dev Biol 1990;139:269-78.

22. Benardeau A, Hatem S, Rücker-Martin C, Tessier S, Dinanian S, Samuel JL, et al. Primary culture of human atrial myocytes is associated with the appearance of structural and functional characteristics of immature myocardium. J Mol Cell Cardiol 1997;29:1307-20.

23. Rücker-Martin C, Hatem S, Dubus I, Mace L, Samuel J, Mercadier J. Behaviour of human atrial myocytes in culture is donor age dependent. Neuromuscul Disord 1993;3:383-90.

24. Eppenberger H, Eppenberger-Eberhart M, Hertig C. Cytoskeletal rearrangements in adult rat cardiomyocyte in culture. Ann N Y Acad Sci 1995;752:128-30.

25. Messerli J, Eppenberger-Eberhardt M, Ritishauser B, Schwarb P, von Arx P, Koch-Schneidemann S, et al. Remodelling of cardiomyocyte architecture visualized by three-dimensional (3D) confocal microscopy. Histochemistry 1993;100:193-202.

26. Hertig C, Butz S, Koch S, Eppenberger-Eberhart M, Kemler R,
Eppenberger H. N-cadherin in adult rat cardiomyocytes in culture. II: Spatio-temporal appearance of proteins involved in cellcell contact and communication. Formation of two distinct Ncadherin/catenin complexes. J cell Sci 1996;109:11-20.

27. Rucker-Martin C, Hénaff M, Hatem S, Delpy E, Mercadier J. Early redistribution of plasma membrane phosphatidylserine during apoptosis of adult rat ventricular myocytes in vitro. Basic Res Cardiol 1999;94:171-9.

28. Delpy E, Hatem S, Andrieu N, de Vaumas C, Henaff M, RuckerMartin C, et al. Doxorubicin induces slow ceramide accumulation and late apoptosis in cultures adult rat ventricular myocytes. Cardiovasc Res 1999;42:398-407.

29. Dubus I, Samuel J, Marotte F, Delcayre C, Rappaport L. B-adrenergic agonist stimulate the synthesis of noncontractile but not contractile proteins in cultured myocytes isolated from adult rat heart. Circ Res 1990;66:867-74.

30. Mikita T, Beardsley G. Functional consequences of the arabinosylcysteine structure lesion in DNA. Biochemistry 1988;27:4698-705.

31. Kufe S, Major P, Egan E, Beardsley G. Correlation of cytotoxicity with incorporation of ara-C into DNA. J Biol Chem 1980;255:8997-9000.

32. Stratford-Perricaudet L, Makeh I, Perricaudet M, Briand P. Widespread long-term gene transfer to mouse skeletal muscles and heart. J Clin Invest 1992;90:626-30.

33. Sauvadet A, Rohn T, Pecker F, Pavoine C. Synergistic actions of glucagon and miniglucagon on $\mathrm{Ca} 2+$ mobilization in cardiac cells. Circ Res 1996;78:102-9.

34. Fabiato A, Fabiato F. Calcium-induced release of calcium from the sarcoplasmic reticulum of skinned cells from adult human, dog, cat, rabbit, rat and frogs hearts and from fetal and new-born rat ventricles. Ann N Y Acad Sci 1978;307:491-522.

35. Eppenberger-Eberhardt M, Messerli M, Eppenberger HM, Reinecke M. New occurrence of atrial natriuretic factor and storage in secretorially active granules in adult rat ventricular cardiomyocytes in long-term culture. J Mol Cell Cardiol 1993;25:753-7.

36. Cima L, Vacanti J, Vacanti C, Ingber D, Mooney D, Langer R. Tissue engineering by cell transplantation using degradable polymer substrates. J Biomech Eng 1991;113:143-51.

37. Cooper M, Hansbrough J, Spielvogel R, Cohen R, Bartel R, Naughton G. In vivo optimization of a living dermal substitute employing cultured human fibroblasts on a biodegradable polyglycolic acid or polyglactin mesh. Biomaterials 1991;12:243-8.

38. Schackow T, Decker R, Ten Eick R. Electrophysiology of adult cardiac ventricular myocytes: changes during primary culture. Am J Physiol 1995;268:C1002-17.

39. Langer R, Vacanti J. Tissue engineering. Science 1993; 260:920-6.

40. Zund G, Breuer C, Shinoka T, Ma PX, Langer R, Mayer JE, et al. The in vitro construction of a tissue engineered bioprosthetic heart valve. Eur J Cardiothorac Surg 1997;11:493-7.

41. Shinoka T, Shum-Tim D, Ma P, Tanel RE, Isogai N, Langer R, et al. Creation of viable pulmonary artery autografts through tissue engineering. J Thorac Cardiovasc Surg 1998;115:536-46.

42. Midha R, Mackinnon S, Wade J, Evans P, Best T, Wong P. Chronic cyclosporin A therapy in rats. Microsurgery 1992;13:273-6.

43. Claycomb W. Control of cardiac muscle cell division. Trends Cardiovasc Med 1992;2:231-6. 